\title{
Zdystansowana zabawa, czyli o adaptacji narzędzi ludycznych w kształceniu na odległość
}

Distanced play, i.e. adaptation of ludic tools in distance education

\section{Paulina Kaźmierczak}

Uniwersytet Łódzki

paulina.kazmierczak@edu.uni.lodz.pl | ORCID: 0000-0002-6980-5988

\begin{abstract}
The aim of the paper is to present difficulties related to the adaptation of materials used in teaching Polish as a foreign language. The tools used so far during stationary classes cannot always be effectively introduced in online lessons. The paper will present the ways of adapting traditional materials and the pros and cons of such a solution. The description of the application of particular forms making distance education more attractive is based on experiences gained during conducting a series of online classes for foreigners.
\end{abstract}

Keywords: adaptation, ludicity, online education, glottodidactics of Polish 



\section{Elementy ludyczne w glottodydaktyce}

Można zaobserwować, że przełom XX i XXI wieku skutkuje w Polsce istotnymi zmianami w kwestii obecności elementów ludycznych w kształceniu językowym. Zmiany te dotyczą nie tylko częstotliwości stosowania tego typu rozwiązań podczas zajęć, lecz przede wszystkim wprowadzania i popularyzowania gier i zabaw w procesie dydaktycznym (Siek-Piskozub, 1994, s. 5-6).

Nie jest to zjawisko odosobnione w kontekście ponowoczesnej pedagogiki, która opiera się na przekonaniu o podmiotowości zarówno ucznia, jak i nauczyciela, a także na ich aktywnym uczestniczeniu w procesie edukacyjnym. Takie podejście sprzyja stosowaniu metod problemowych, które zakładają większą sprawczość uczących się oraz odchodzenie od pasywnych form podających. Wskazana tendencja ma ścisły związek z definicją terminu „zabawa” (Siek-Piskozub, 2001, s. 9-12).

Znaczenie tego leksemu nie jest tak oczywiste, jak mogłoby się wydawać, biorąc pod uwagę powszechność przejawów ludyczności w codziennym życiu. Zabawa ma charakter pierwotny - jest bowiem starsza od kultury, czego potwierdzenie stanowi obserwowanie jej również w świecie zwierząt - lecz mimo to jej definicje są nieco odmienne w zależności od języka. Nie brakuje bowiem społeczności, które wskazują rozbieżność między określeniami „zabawa” oraz „gra”, jednak można znaleźć także grupy nieuznające takiego podziału za konieczny, co pozwala wysnuć wnioski w kwestii roli, jaką ludyczność odgrywa w ich kulturze (Huizinga, 1998, s. 11-21).

Warto podkreślić, że wielość leksemów nazywających działania związane z rozrywką wpływa w istotny sposób na potencjał ich dokładnej separacji semantycznej. Nie da się ukryć, że konotacje i denotacje określeń „zabawa”, „gra”, a nawet „symulacja” wzajemnie się przenikają. Pierwsze z nich nazywa działania, które niejednokrotnie stanowią imitację zachowań obserwowanych przez dzieci w codziennym życiu dorosłych. Dopiero z czasem ewoluują do postaci sekwencji decyzji lub czynności skutkujących możliwością oceny zgodnie z punktową skalą będącą elementem zasad rozgrywki (Siek-Piskozub, 2001, s. 23-27).

Niezależnie od przyjętej definicji oraz od wybranego terminu nie sposób wykluczyć aktywnego udziału uczestników zajęć, w trakcie których 
stosuje się - w procesie kształcenia - elementy ludyczne. W tym przypadku działania i zachowania ucznia mające celu uczynienie przyswajania wiedzy skutecznym i przyjemnym bezpośrednio wiążą się z realizacją zasad gry. Tym samym strategie uczenia się i nauczania są ze sobą nierozerwalnie złączone. Warto zaznaczyć, że nie muszą być tożsame, ponieważ bezpośredni cel kształcenia przyjęty przez nauczyciela, czyli przekazanie określonej wiedzy, staje się w kontekście postawy uczniowskiej - dla samego ucznia - efektem pośrednim. Istotą są bowiem rywalizacja i zabawa (Siek-Piskozub, 2007, s. 13-18). Wykorzystanie w nauczaniu technik nawiązujących do ludycznej działalności człowieka Teresa Siek-Piskozub nazywa strategią ludyczną, owe techniki zaś - technikami ludycznymi (Siek-Piskozub, 2001, s.19-20). Do technik tego rodzaju zalicza trzy podstawowe grupy zajęć: gry, zabawy (w tym muzykę i piosenkę) oraz symulacje, a także istniejące formy pośrednie między wymienionymi (tamże, s. 32-35).

Choć popularność strategii ludycznej jest zdecydowanie większa w gronie uczniowskim niż nauczycielskim (Siek-Piskozub, 2007, s. 18-21), to konieczność kształcenia na odległość zmusiła prowadzących zajęcia nie tylko do korzystania z nowinek technologicznych, ale również do odkrywania możliwości nieznanych dotąd narzędzi online. Większość z nich z założenia wpisuje się w kategorię ludyczności ze względu na swoją funkcję oraz sposób, w jaki zostały skonstruowane.

Ludyczność to obszerne pojęcie, obejmujące różne aspekty działań edukacyjnych. Należą do nich: elementy muzyczne, w tym piosenki (Siek-Piskozub, Wach, 2006), zabawy: tematyczne, konstrukcyjne, ruchowe bądź dydaktyczne, a także gry: losowe, strategiczne, strategiczno-losowe. Inne podziały dotyczą stopnia imitacji (niesymulacyjne, symulacyjne) lub struktury (sytuacyjne, biograficzne czy inscenizacyjne) (Siek-Piskozub, 1994, s. 10-16).

Nie bez znaczenia pozostaje kwestia zmiany koncepcji edukacji, a tym samym ról ucznia oraz nauczyciela. $Z$ biernego odbiorcy adresat procesu kształcenia staje się kreatywnym twórcą, natomiast dotychczasowy mistrz przekazujący wiedzę dostępną nielicznym pełni funkcję przewodnika, który kieruje do źródeł wiedzy i motywuje do ich konstruktywnego zgłębiania oraz niesztampowego utrwalania (Żylińska, 2007, s. 94-96). Ta zmiana jest szczególnie istotna w kontekście informacyjnej globalizacji 
wywołanej powszechnym dostępem do internetu, a także masową zmianą formy pracy z edukacji stacjonarnej na kształcenie zdystansowane.

\section{Ludyczność w glottodydaktyce polonistycznej}

Warto zastanowić się nad powodami wybierania gier i zabaw przez lektorów języków obcych, w szczególności uczących języka polskiego jako obcego. Podstawowy podział, którego można dokonać, obejmuje przyczyny bezpośrednie i pośrednie. W pierwszej grupie mieści się świadoma decyzja nauczyciela - pewność, że korzystanie z wciąż niestandardowych, w kontekście edukacyjnym, rozwiązań może prowadzić do zaskakująco pozytywnych efektów. Ponadto ważny jest aspekt innowacyjności oraz stosowania nowoczesnych technologii podczas lekcji. W drugim przypadku nie bez znaczenia pozostaje rynek wydawniczy, który współkreuje wybór materiału, oferując coraz nowocześniejsze zbiory gier i zabaw językowych uatrakcyjniających zajęcia. Pośrednim czynnikiem wpływającym na decyzje lektorów jest także obecna sytuacja epidemiczna, a co za tym idzie, konieczność pracy zdalnej. Rzeczywistość wirtualna otwiera przed nauczycielami większe możliwości stosowania narzędzi online o charakterze ludycznym.

Warto zaznaczyć, że nie dotyczy to jedynie młodych osób, ale również tych potencjalnie najbardziej zagrożonych wykluczeniem cyfrowym ze względu na wiek. Edukatorzy działający w ramach programu Latarnicy2020 wyszli naprzeciw potrzebom wielu tysięcy Polaków, organizując szkolenia z rozwoju kompetencji cyfrowych dla osób powyżej 44 roku życia (Latarnicy2020.pl, 2020). Wśród warsztatów o zasięgu zarówno ogólnopolskim, jak i regionalnym nie zabrakło oferty skierowanej do nauczycieli. Dzięki temu pracownicy sektora edukacji z województwa opolskiego i dolnośląskiego mogą doskonalić umiejętności z zakresu obsługi narzędzi online wspomagających pracę z uczniami (Latarnicy 2020 Cała Polska, 2021).

Nie sposób pominąć faktu, że wszelkie działania mające na celu rozwój kompetencji cyfrowych obejmują jedynie techniczne aspekty wykorzystywania dostępnych aplikacji. W zależności od przedmiotu, którego uczy się ich użytkownik, należy dokonać serii modyfikacji oferowanych 
szablonów lub zastosować rozwiązania stworzone i zamieszczone $\mathrm{w}$ internecie przez innych nauczycieli. W kontekście glottodydaktyki polonistycznej, rozumianej za Władysławem Miodunką (2016, s. 54) jako badanie procesu kształcenia i przyswajania języka polskiego jako obcego lub drugiego, trudno o znalezienie gotowych materiałów w sieci. W tej kwestii ułatwienia dotyczą przede wszystkim anglistów, którzy mogą korzystać z wielu międzynarodowych platform i z pomocy dydaktycznych opracowywanych przez lektorów na całym świecie. Również poloniści pracujący z rodzimymi użytkownikami języka mają łatwiejsze zadanie, ponieważ aktywność internetowa wspomnianej grupy zawodowej gwałtownie wzrosła w czasie epidemii, a tym samym umożliwiła nie tylko szerszą wymianę informacji, lecz również dzielenie się materiałami online, których jakość może być porównywalna z dokonaniami anglistów. Nie ulega wątpliwości, że oprócz kompetencji cyfrowych istotnym elementem jest też kreatywność. Trudność polegającą na konieczności wymyślania i tworzenia nowych gier lub zabaw językowych łatwo rozwiązać podczas zajęć stacjonarnych, gdy mamy do dyspozycji bogatą ofertę gotowych pomocy dydaktycznych sporządzonych przez wydawnictwa. Jednak w przypadku lekcji online wydają się one bezużyteczne. Jednym z rozwiązań jest adaptacja dostępnych materiałów tak, aby można było z nich korzystać podczas zajęć prowadzonych zdalnie.

\section{Adaptacja gotowych pomocy dydaktycznych}

Najprostsze zadania ludyczne, np. wykreślanki, krzyżówki lub rebusy, łatwo przenieść do przestrzeni wirtualnej przy pomocy generatorów online (Kaźmierczak, 202ob, s. 119-127). Celem niniejszego artykułu jest natomiast przedstawienie sposobów dostosowywania gier planszowych, jako jednej z możliwych form nauki języka polskiego jako obcego, do potrzeb zajęć zdalnych. Istnieje wiele wariantów użytkowania planszy w trakcie lekcji stacjonarnych, istotą tego tekstu jest wszakże zwrócenie uwagi na kilka najważniejszych aspektów pracy z narzędziami ludycznymi online. Należą do nich: poziom kompetencji cyfrowych niezbędnych do wykonania adaptacji, czasochłonność tego procesu oraz konieczność wielokrotnego wykorzystania otrzymanej pomocy dydaktycznej. 
Pierwszym etapem jest zeskanowanie planszy z wybranego zestawu gier i zabaw oferowanego przez wydawnictwo Glossa, specjalizujące się w publikacjach z zakresu glottodydaktyki polonistycznej (Stempek, 2012). Najłatwiejszym sposobem wprowadzenia gry w tok zajęć jest otworzenie pliku PDF w bezpłatnej aplikacji, która umożliwia nie tylko jego odczytanie, ale także edycję, np. Adobe Acrobat Reader DC.

Następnie należy podjąć decyzję dotyczącą formy pracy ze zdigitalizowaną planszą. Można owe działania przeprowadzić w kilku wariantach z kostką lub bez niej, a także z wykorzystaniem mikrofonu bądź czatu. Pierwsze rozróżnienie zakłada, że każdy uczeń dysponuje kostką, którą rzuca, kiedy nadejdzie jego kolej. Wynik rzutu może pokazać przy pomocy kamerki internetowej lub po prostu podać (jeśli zakładamy uczciwość gracza). Wówczas zamiast pionków stosowane są oznaczenia w postaci różnokształtnych symboli lub kolorowych kropek - ich „przesuwanie” koordynuje lektor albo poszczególni uczniowie, jeśli komunikator używany do prowadzenia zajęć umożliwia oddawanie współrozmówcom kontroli nad udostępnianym ekranem.
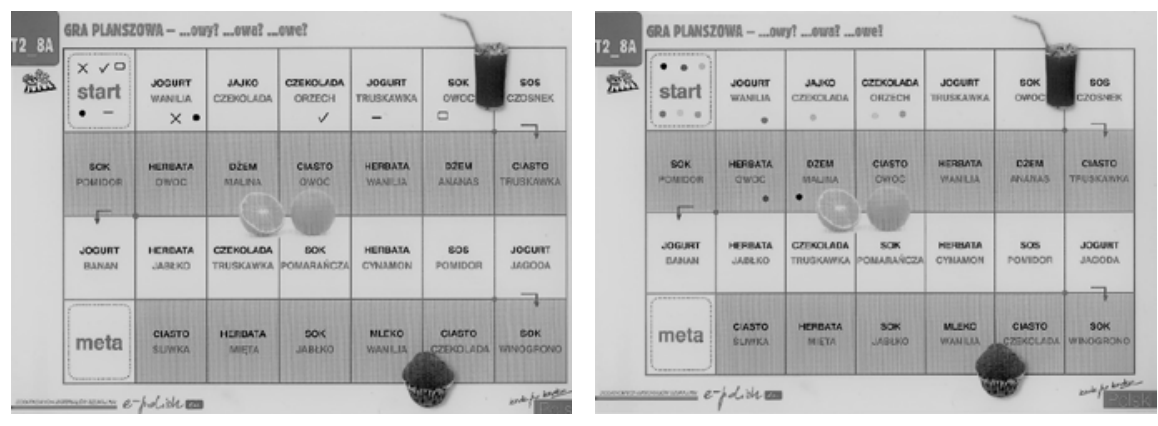

Ilustracja 1. Dwa warianty pionków stosowane w adaptacji dokonywanej przy pomocy czytnika plików PDF

Kolejne opcje uwzględniają rozgrywkę bez kostki. Proces ten może przebiegać dwojako - studenci po kolei odmieniają leksemy znajdujące się na poszczególnych polach planszy lub lektor rozpoczyna indywidualne konwersacje na czacie z każdym uczniem i prosi o wypisanie właściwych form wszystkich wyrazów. Ostatnie rozwiązanie stanowi duże ułatwienie w sytuacji, gdy ze względu na kłopoty techniczne usłyszenie uczniów jest niemożliwe bądź utrudnione. Warianty bez kostki nie wymagają 
stosowania pionków, jednak konieczna okazuje się modyfikacja w kwestii wyłonienia zwycięzcy. Nie jest nim bowiem ten, kto pierwszy znajdzie się na mecie, lecz osoba, która uzyska najwięcej poprawnych odpowiedzi. W celu uniknięcia korzystania przez graczy z notatek lub internetu należy wyznaczyć określony czas na udzielenie odpowiedzi - zarówno w wariancie ustnym, jak i pisemnym. Rozgrywka będzie najbardziej efektywna w grupie do sześciu osób, jednak opcje bez użycia kostki pozwalają na przeprowadzenie zabawy również w większym gronie. Adaptacja nie jest czasochłonna, wymaga bowiem od lektora jedynie umiejętności obsługi aplikacji do odczytywania skanów w formacie PDF, co czyni ją narzędziem uniwersalnym.

Innym sposobem na wykorzystanie planszy podczas zajęć jest zastosowanie aplikacji Classroomscreen. Umożliwia ona umieszczenie ilustracji wykonanego wcześniej skanu, a także interaktywnej kostki do gry lub wyszukiwarki imion na specjalnym ekranie klasowym, który widzą uczniowie. W pierwszym przypadku studenci przy pomocy kostki losują pole, a tym samym dowiadują się, które wyrazy powinni odmienić. Nauczyciel czuwa jedynie nad weryfikacją poprawności zarówno pod względem gramatycznym, jak i technicznym. W drugim lektor umieszcza wcześniej imiona poszczególnych osób z grupy w wyszukiwarce, ona zaś wskazuje, kto z graczy będzie musiał zrealizować zadanie umieszczone na danym polu. Niestety, w darmowej wersji opisywanego narzędzia nie ma możliwości zapisywania utworzonych projektów, musi odbywać się bezpośrednio przed zajęciami online. Na szczęście nie jest to proces czasochłonny.

Warto rozważyć także potencjał aplikacji Genial.ly, która oferuje gotowe grafiki w postaci edytowalnych szablonów. W zależności od potrzeb wybór obejmuje grę, quiz, infografikę i wiele innych interesujących form wizualnych, a nawet audiowizualnych (Kaźmierczak, 2020b, s. 559-570). Na potrzeby niniejszego tekstu zdecydowano się na przedstawienie dwóch opcji wykorzystania potencjału wspomnianego narzędzia. Pierwszą z nich jest szablon graficzny typu click to action, umożliwiający obrócenie grafiki oraz powrót do wersji pierwotnej (Genial.ly, 2020a). Dzięki temu na pierwszej stronie umieszczono skan planszy, a na drugiej liczby od 1 do 26. Pod każdym numerem kryje się imię jednej osoby z grupy. Po rozpoczęciu gry lektor prezentuje pole z leksemami, które 

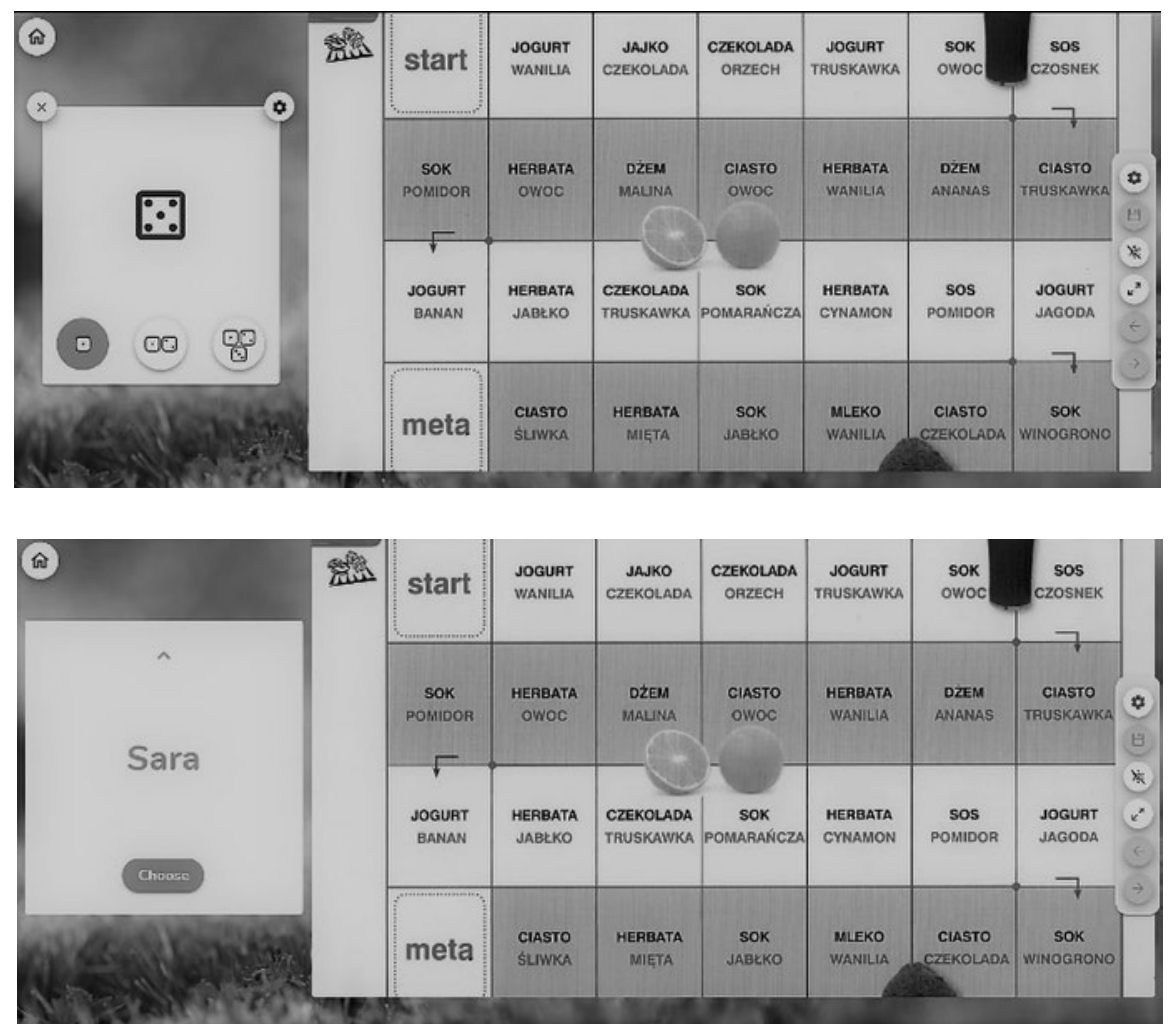

Ilustracja 2. Dwa warianty planszy w aplikacji Classroomscreen

za chwilę odmieni jeden ze studentów. Następnie prowadzący klika na pytanie: „Kto odpowiada?”, i prosi wybraną osobę z grupy o wybranie liczby spośród widocznych na ekranie. Gdy nauczyciel klika na ów numer, pojawia się imię jednego z członków grupy; on właśnie powinien odmienić wyrazy. Potem ów uczeń w analogiczny sposób wskazuje kolejnego gracza. Cel rozgrywki stanowi wymienienie największej liczby poprawnych form odmiany. Warto pamiętać, że w tym przypadku konieczne jest zadbanie o taką samą liczbę szans na udzielenie odpowiedzi dla każdego uczestnika. Opisany wariant wymaga modyfikacji szablonu pod kątem tła - skanu planszy, oraz dodawania i opisywania elementów graficznych ułatwiających wybór odpowiadającego. Aplikacja ma charakter intuicyjny, a szablon - w pełni edytowalny, więc użytkownik nie musi posiadać kompetencji graficznych. Zaletą adaptacji jest z pewnością jej prostota i możliwość wielokrotnego wykorzystywania. 

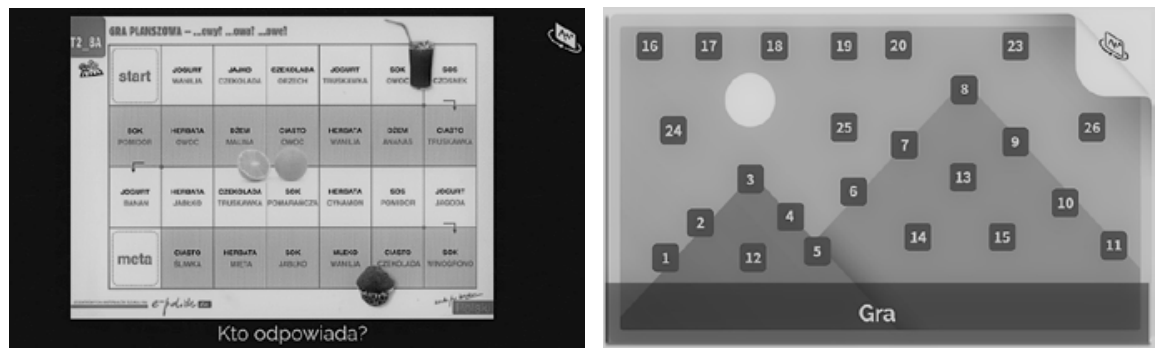

Ilustracja 3. Obracająca się grafika (click to action) w aplikacji Genial.ly

Inny pomysł na zastosowanie tej samej aplikacji podczas kształcenia zdalnego stanowi adaptacja typowego szablonu gry planszowej. W tym przypadku chodzi o format inspirowany popularnym filmem przygodowym Jumanji (Genial.ly, 202ob). Niezbędna okazuje się jednak zamiana pierwotnej planszy na skan gotowej pomocy dydaktycznej. Atutem korzystania z tego rodzaju szablonu jest wirtualna kostka, zatrzymująca się dopiero na skutek kliknięcia gracza. Ponadto uczniowie mają do dyspozycji cztery pionki, które mogą dowolnie przesuwać na planszy, jeśli podczas lekcji lektor odda im kontrolę nad ekranem. W przypadku bardziej zaawansowanych grup istnieje opcja utrudnienia zadań znajdujących się na poszczególnych polach poprzez umieszczenie tam elementów zawierających dodatkowe polecenia. Jeśli zajęcia językowe odbywają się w większym gronie niż cztery osoby, dobre rozwiązanie stanowi gra zespołowa. Przy odpowiedniej modyfikacji zadań drużyny mogą liczyć nawet po trzy osoby. Ten wariant jest bardziej pracochłonny i wymaga większego zaangażowania lektora w edycję szablonu, ale zachęca w tym przypadku możliwość zapisania projektu - w darmowej wersji musi on w owym celu mieć status publiczny - a tym samym jego ponownego wykorzystania.
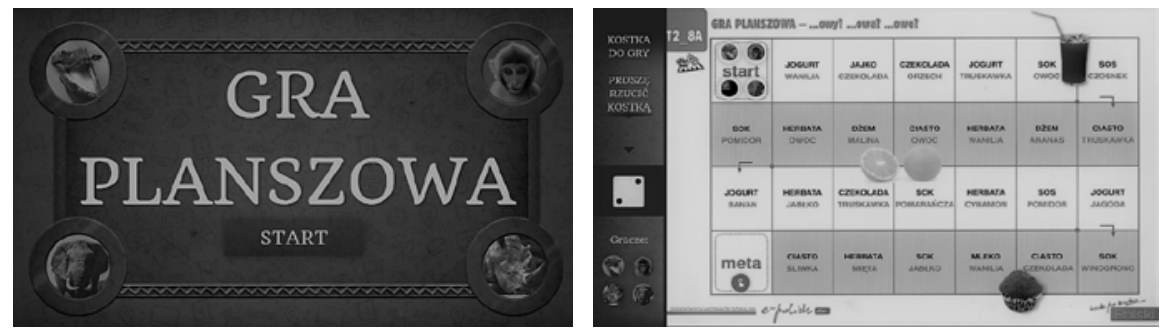

Ilustracja 4. Gra planszowa inspirowana grafiką z filmu Jumanji - aplikacja Genial.ly 
Ostatnia propozycja to adaptacja wykonana w aplikacji QuizWhizzer. Narzędzie to pozwala na skonstruowanie gry planszowej, w której użytkownik może nie tylko dobrać tło, ale także ułożyć własne pytania, m.in. w formie testu wyboru, oceny poprawności typu prawda-fałsz lub krótkich odpowiedzi pisemnych. W przypadku gotowego tła, którego funkcję pełni skan rzeczywistej planszy, zadaniem lektora pozostaje dodanie krótkiego quizu. Pytania dotyczą choćby rodzaju rzeczownika, do którego dobierana jest odmiana przymiotnikowa. Oprócz udzielania ustnych odpowiedzi do zadań umieszczonych na planszy i weryfikowanych na bieżąco przez nauczyciela gracze dodatkowo rywalizują w rozwiązywaniu testów na komputerach lub telefonach komórkowych w zależności od wykorzystywanego sprzętu. Efekty są widoczne w czasie rzeczywistym na ekranie udostępnianym przez lektora. Przygotowanie adaptacji z pomocą narzędzia QuizWhizzer wymaga przede wszystkim czasu, a także kreatywności w kwestii sposobu stosowania aplikacji. Można bowiem zarówno poprosić uczniów o indywidualną pracę nad quizem, a także o przesłanie na czacie rozwiązań do gotowych zadań na planszy, jak i pozostać przy wariancie grupowym. W tym drugim przypadku odpowiedzi udzielane są rotacyjnie przez wszystkich uczestników zajęć, a treść pytań widać na monitorze lektora. Fakt, że przygotowana adaptacja jest wielokrotnego użytku, to jednocześnie wada i zaleta opisywanego narzędzia. Przyczynia się do tego ograniczona liczba rozgrywek. Użytkownicy darmowej wersji aplikacji mogą grać trzy razy na miesiąc. Jednak potencjał cyklicznego wykorzystywania efektów pracy nauczyciela stanowi przewagę QuizWhizzera wobec aplikacji Classroomscreen.
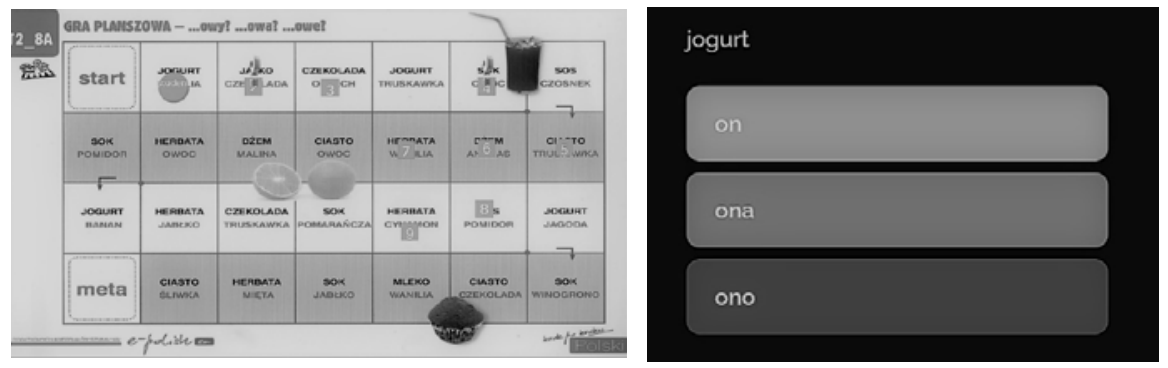

Ilustracja 5. Plansza i dodatkowe pytania w formie quizu przygotowane w aplikacji QuizWhizzer 


\section{Wnioski}

Współcześnie coraz częściej stosowane jest zestawienie słów „nauka” oraz „zabawa”. Ludyczny wymiar edukacji znajduje odzwierciedlenie również podczas nauczania zdalnego. Co więcej, stanowi jego istotną część także w pracy glottodydaktyków polonistów, którzy oprócz przekazywania wiedzy językowej starają się edukować studentów w zakresie kultury (Žák-Caplot, 2020), nie pomijając jej popularnych przejawów (Kajak, 2020). Możliwości aplikacji do konstruowania gier, grafik, quizów stają się nie tylko podstawą samokształcenia nauczycieli, ale też inspiracją do badań (Gruza, Pabiańczyk, 2016). Warto jednak pamiętać, że oprócz niewątpliwych zalet wykorzystywania nowoczesnych technologii w nauczaniu języka polskiego jako obcego wciąż aktualny jest problem poziomu kompetencji cyfrowych lektorów. Do jego rozwiązania przyczynić się mają szansę liczne szkolenia (doskonalące umiejętności polonistów), a także możliwość pracy w intuicyjnych aplikacjach, które uatrakcyjniają materiały pod względem graficznym i sprawiają, że zajęcia są bardziej interaktywne. Mimo to wciąż istotnym utrudnieniem pozostaje kwestia pomysłu na zdalne pomoce dydaktyczne o charakterze ludycznym.

W artykule przedstawiono sposób na rozwiązanie wskazanego problemu. Jest nim adaptowanie gotowych narzędzi o formie tradycyjnej do wersji online. Poszczególne warianty, opisane w tekście, różnią się sposobem prowadzenia rozgrywki, liczebnością grupy, a także czasem potrzebnym na przystosowanie istniejących materiałów oraz poziomem kompetencji cyfrowych wymaganym od lektora, który chciałby podjąć się stworzenia adaptacji. Oprócz możliwości, jakie oferują poszczególne narzędzia online, najistotniejszym zagadnieniem w kwestii dostosowywania posiadanych materiałów są prawa autorskie. Ryzyko ich naruszenia obliguje do korzystania z aplikacji niewymuszających upubliczniania spreparowanych pomocy dydaktycznych lub umożliwiających wykupienie pakietu ograniczającego dostęp dla osób trzecich.

\section{Literatura}

Genial.ly (2020a). Adaptacja 1. Online:<https://view.genial.ly/5fb8e1f4c48a49o d2894egeo/game-action-gra-adaptacja-1>. Data dostępu: 30 grudnia 2020. 
Genial.ly (2020b). Adaptacja 2. Online: <https://view.genial.ly/5fb8e979 7eb777ocfdb2bo53/game-gra-adaptacja-2>.

Gruza, D., Pabiańczyk, A. (2016) Język polski 2.0 - zastosowanie nowoczesnych technologii $w$ nauczaniu języka polskiego. Warszawa: Fundacja Edu\&More. Online: <https://issuu.com/fundacjaedumore/docs/publikacja_jezyk_polski_2.o_-_zasto>.

Huizinga, J. (1998). Homo ludens. Zabawa jako źródło kultury (tłum. M. Kurecka, W. Wirpsza) Warszawa: Czytelnik.

Kajak, P. (2020). Kultura popularna w nauczaniu polszczyzny jako języka obcego. Warszawa: Wydawnictwo Uniwersytetu Warszawskiego.

Kaźmierczak, P. (2020a). Czy aplikacja Genial.ly rzeczywiście jest genialna? O potencjale narzędzi online podczas zdalnego nauczania języka polskiego jako obcego. Acta Universitatis Lodziensis. Kształcenie Polonistyczne Cudzoziemców, 27(1), 559-570. Online: <https://czasopisma. uni.lodz.pl/kpc/article/view/8983/8793>.

Kaźmierczak, P. (2020b). Elementy ludyczne w kształceniu lektorów języka polskiego jako obcego. W: M. Biernacka, P. Kaźmierczak, A. Banach (red.), Ludyczność w (glotto)dydaktyce (s. 119-127). Łódź: Wydawnictwo Uniwersytetu Łódzkiego.

Lararnicy2020.pl (2020). Projekt „Latarnicy Polski Cyfrowej 2020”. Kilka słów o projekcie. Online: <https://latarnicy2020.pl/o-projekcie>.

Latarnicy 2020 Cała Polska (6 stycznia 2021). Darmowe warsztaty: Genially, Canva, Teams, Quizizz, Quizlet, Wordwall Meet itp. Online: <https:// www.facebook.com/events/390942745670382>.

Siek-Piskozub, T., Wach, A. (2006). Muzyka i słowa. Rola piosenki w procesie przyswajania języka obcego. Poznań: Wydawnictwo Naukowe UAM.

Siek-Piskozub, T. (1994). Gry i zabawy w nauczaniu języków obcych. Warszawa: Wydawnictwa Szkolne i Pedagogiczne.

Siek-Piskozub, T. (2001). Uczyć bawiąc. Strategia ludyczna na lekcji języka obcego. Warszawa: Wydawnictwo Naukowe PWN.

Siek-Piskozub, T. (2007). Strategia ludyczna $w$ glottodydaktyce. W: A. Surdyk, Kulturotwórcza funkcja gier. Gra jako medium, tekst i rytuat. Tom 1 (s. 13-28). Poznań: Wydawnictwo Naukowe Uniwersytetu im. Adama Mickiewicza.

Stempek, I. (2012). Polski krok po kroku. Gry i zabawy językowe 1. Kraków: Wydawnictwo „Glossa”. 
Žák-Caplot, K. (2020) Jak i dlaczego uczyć języka polskiego jako obcego w muzeum? Techniki pracy z grupa i tworzenie materiałów językowych na przykładzie projektu Muzeum Warszawy „Warszawa dla średnio zaawansowanych". W: E. Kubicka, M. Berend, A. Walkiewicz (red.), Nowe perspektywy w nauczaniu języka polskiego jako obcego V (s. 285-299). Toruń: Wydawnictwo Naukowe Uniwersytetu Mikołaja Kopernika.

Żylińska, M. (2007). Postkomunikatywna dydaktyka języków obcych w dobie technologii informacyjnych. Teoria i praktyka. Warszawa: Wydawnictwo „Fraszka Edukacyjna”.

Data dostępu do źródeł internetowych wykorzystanych w tekście: 30 grudnia 2020.

mgr Paulina Kaźmierczak - doktorantka w Zakładzie Lingwistyki Stosowanej i Kulturowej Uniwersytetu Łódzkiego oraz lektorka języka polskiego jako obcego. Interesuje się strategią ludyczną w procesie glottodydaktycznym. Szczególną uwagę poświęca stosowaniu nowoczesnych technologii oraz adaptacji piosenek, reklam, a także gier karcianych, planszowych i fabularnych na potrzeby zajęć językowych.

\section{Zdystansowana zabawa, czyli o adaptacji narzędzi ludycznych w ksztatceniu na odległość}

Abstrakt: Celem artykułu jest przedstawienie trudności związanych $z$ adaptacją materiałów wykorzystywanych podczas nauczania języka polskiego jako obcego. Narzędzia używane dotychczas w czasie zajęć stacjonarnych nie zawsze mogą być skutecznie wprowadzane na lekcjach online. W artykule zaprezentowane są sposoby adaptacji tradycyjnych materiałów oraz wady i zalety takiego rozwiązania. Opis zastosowania poszczególnych form uatrakcyjniających kształcenie na odległość został oparty na doświadczeniach zebranych w trakcie prowadzenia cyklu zdalnych zajęć dla obcokrajowców.

Słowa kluczowe: adaptacja, ludyczność, edukacja online, glottodydaktyka polonistyczna 